\title{
MULTI CRITERIA DECISION MAKING FOR ASSISTING BUSINESS ANGELS IN INVESTMENTS
}

\author{
Reza ROSTAMZADEH ${ }^{\mathrm{a}}$, Kamariah ISMAIL ${ }^{\mathrm{b}}$, Edmundas Kazimieras ZAVADSKAS ${ }^{\mathrm{c}}$ \\ ${ }^{a, b}$ Department of Management, Universiti Teknologi Malaysia, \\ 81310 Skudai, Johor, Malaysia \\ 'Department of Construction Technology and Management, Vilnius Gediminas Technical University, \\ Sauletekio al. 11, 10223 Vilnius, Lithuania
}

Received 07 March 2014; accepted 06 July 2014

\begin{abstract}
The roles of business angels (BAs) are especially important in view of both decreasing the levels of formal venture capital investment and growing the average amount of individual deals. Angel investors typically invest at an earlier stage of growth and provide more business guidance than venture capital providers. Therefore, angel investors are the key players in generating high-growth companies, essential to regional economic development. As a result, they have attracted the attention of policy makers. Thus, this research attempted to improve the conception of decision-making criteria used by the BAs for investment, and reports the findings of an exploratory project that analysed the Malaysian BAs' decision-making process. A hierarchy of multiple criteria decision making (MCDM) model based on fuzzy sets theory and VIKOR (in Serbian: Vise Kriterijumska Optimizacija I Kompromisno Resenje) method were proposed in order to look into the decision making process. For this reason, 5 main criteria and 29 sub criteria were developed to be evaluated by 5 well-known BAs to assess and rate the criteria and alternatives using fuzzy linguistic variables. For the purpose of illustration, an empirical case study was conducted on Malaysian BAs and the results are presented with numerical examples. The final finding of the research suggested that Johor is the most suitable city for investment. Kuala Lumpur, Penang, and Sabahare placed in the subsequent ranks. The proposed framework had been successfully applied for the decision making process, and could be used by other BAs for their cases with slight modifications.
\end{abstract}

Keywords: business angels, investment criteria, regional development, decision making, fuzzy sets, MCDM, VIKOR.

JEL Classification: C02, C44, C65, D81, M13, O16, R58.

Corresponding author Kamariah Ismail

E-mails:m-maria@utm.my; rostamzadeh59@gmail.com 


\section{Introduction}

There has been an increasing number of examples around the world regarding programmes and policies to support angel investment, ranging from tax incentives to co-investment funds, to support national angel associations, groups, and networks. Policies that work in one country may not necessarily work the same way, or be as successful, in another country. Another challenge for policy makers and practitioners alike is that there are limited data, as well as lack of clarity of definitions, therefore it is hard to measure the angel market. At the same time, there has been limited formal evaluation of these policies and programmes to date, so further work is needed in this area.

What criteria do business angels (BAs) use to make venture investment decisions? For several reasons, the criteria used by them are of interest, as stated by Hall and Hofer (1993). Firstly, they are noticeably successful in their investment decisions. A better understanding of the reasons for this success could be perceived by a better understanding of the criteria used. Next, improvement in the success rate of the new ventures could be obtained via the better understanding of the criteria for the successful new ventures. Even though the failure rate among the new ventures is normally higher than the average failure rate, there is no clear agreement on the exact rate. Finally, the investment criteria of the venture capitalist carry great importance to entrepreneurs seeking venture funding. Such entrepreneurs require a significant infusion of capital in order to develop their businesses, and the criteria knowledge captured by venture capitalists can aid entrepreneurs in gaining the necessary finance. From a BA's perspective, Mason and Rogers (1997) and Mason and Harrison (2002) suggested that most investors do have a set of clear defined investment criteria which influence the type of businesses that they consider investing in, though these criteria may be relaxed in certain circumstances, notably when the entrepreneur/management team has a high credibility. In general terms, to create both knowledge and awareness is a challenging task among the BAs, especially regarding the preferences used by the investors for choosing investments, and their reasons for turning down an investment. This will help the service providers to offer the entrepreneurs the right information, and thereby, increase the level of investment readiness among the investment-seeking entrepreneurs. The information gap in the informal capital market will be reduced over the long term, and will result in a larger amount of investments committed by the BAs in the appropriate projects (Gullander, Napier 2003).

Since the past few years, decision theory and methods based on fuzzy information have been rapidly developed (Liu, Yu 2013; Hajiagha et al. 2013; Jin et al. 2013; Wei et al. 2012), especially researches based on evaluation information of linguistic form, which have been the concern of many scholars. The multi-criteria decision making (MCDM) approach is appropriate to reflect the BAs preferences for investment as its strength is the consideration of various criteria simultaneously, because the real world of problems regarding decision making cannot be resolved by single criterion and characteristic in today's competitive environment. The importance of each criterion can also be reflected when evaluating the alternatives. Among the several MCDM approaches available, the VIKOR (in Serbian: Vise Kriterijumska Optimizacija I Kompromisno Resenje) method (Opricovic 1998; Opricovic, Tzeng 2002) was utilized in the present study. VIKOR is a compromise ranking method 
to optimize the multi-response process. It is used to rank the alternatives and select them from a set in the presence of conflicting criteria based on the closeness to the ideal solution. VIKOR has some advantages compared to other MCDM approaches. It can solve discrete decision making problems with conflicting and non-commensurable (different units) criteria (Opricovic, Tzeng 2004) and provide a solution that is the closest to the ideal. It determines compromise solutions for a problem with conflicting criteria, which can help the decision makers to reach a final decision (Opricovic, Tzeng 2007; Wei, Lin 2008; Opricovic 2011; Liu et al. 2013).

This paper contributes to the literature in a determinate sense. Firstly, this paper adds to the growing body of research regarding the BAs investment criteria. Although the works on the issue have been increasing in numbers, no previous studies found had applied the MCDM approach to evaluate the criteria used by the BAs for investment. This is one of the first studies in actual evaluation of investment criteria to assist the BAs in decision-making. Secondly, this research contributes to the knowledge in the area of BA investment decision-making. Despite the significant number of academic researches that have undertaken the field of BAs, little is known about the decision-making process of angel investors as the important contextual factor, and most of them have a tendency to maintain a low public profile. For this reason, the VIKOR method developed in fuzzy environment was used to evaluate and prioritize the most important investment criteria and to choose the city with the highest potential for investment. Furthermore, this paper reports the findings of an exploratory project that analysed the Malaysian BAs' decision-making process investment criteria, as it was difficult to locate and conduct a survey on these BAs. To the best of our knowledge, this is the first empirical study that addressed the BAs' decision making using the MCDM approach.

The article proceeds as follows: firstly, the literature on the BAs' decision-making and VIKOR method was reviewed. Then, the methodology adopted is explained, followed by the description of the cases for Malaysian BAs, along with its application. Finally, the results of the pilot study, conclusion, and suggestions for the future studies are clarified.

\section{Literature review}

\subsection{Overview}

Many studies (Tyebjee, Bruno 1984; Macmillan et al.1985, 1987; Kumar, Kaura 2003) have looked into venture capitalists (VCs) and the resources that they have used to assess new ventures. They have identified the importance of certain criteria attributable to potential business plans. These studies have discovered that the process of venture screening is a simple, but a highly skillful activity; hence the potential of a business plan based on certain criteria was measured by the VCs quickly. Many researchers assume that the BAs make their investment decisions in a similar manner as the VCs. As a consequence, the BAs use evidence from the VCs' decisions when proposing their decisions. Since there are differences between the BAs and the VCs' motivations that influence their decision processes, the above said statement is incorrect. Additionally, fund-seeking entrepreneurs pitching to the BAs can be misled by this false supposition and it will cause them to interact with and make presentations to the 
BAs that in the end will not only increase their likelihood of investment attractiveness, but can also reduce it. Van Osnabrugge (2000) believed that the fundamental agency difference is the most important difference between the BAs and the VCs that influences the investment decision. BAs invest their own money and do not need to justify and validate their decisions to anyone, while VCs are professional fund managers who need to justify and defend their selection and rejection of decisions to their investors. VCs have a tendency to invest in a number of companies over a set time frame concentrating within a certain domain. On the other hand, the BAs want to invest in a more limited number of opportunities, but over a broader range of industries and they are not forced by portfolio requirements (Mason, Harrison 2002; Schwarzkopf et al. 2010).

There is a number of key investment criteria used by the VCs for evaluating business proposals of entrepreneurs. The size and attractiveness of the market (Tyebjee, Bruno 1984), management capabilities and functional skills (Wells 1974), the uniqueness of a product or service (Fried, Hisrich 1994), market acceptance of a product, and the degree of competitiveness in the marketplace (MacMillan et al. 1985, 1987; Muzyka et al. 1996) are among the most significant investment criteria in a VC's repertory. Macmillan et al. (1985) investigated the criteria used by the VCs to evaluate new venture proposals. They have used 5 categories of criteria in their study, with a total of 24 criteria that were evaluated. A questionnaire was used to determine the most important criteria that the VCs applied to decide when funding for new ventures. The most important finding from the study was the direct confirmation of the frequently repeated position taken by the venture capital community that above all it is the quality of the entrepreneur that ultimately determines the funding decision. Muzyka et al. (1996) also concluded that the management team's considerations dominate the investment decision. Macmillan et al. (1987) have studied the patterns of successful and unsuccessful ventures. They pointed out how successful ventures can be distinguished from the unsuccessful ventures once the five major classes of risk management are identified. Feeney et al. (1999) found that the BAs consider both attributes of the business and entrepreneurs when deciding to invest in a proposal. They noted that the investors' perception on poor management is the primary deal killer. However, the management's ability, although important, is not the primary factor that attracts investors to a deal. Haines et al. (2003) identified that the people in the project are the most critical factor in the BAs' decision to invest: "many investors said that they would be spending considerable time with these people so it is important that the people be the right ones for the job and be individuals with whom the investors would like to spend some time". The differences of the investment criteria used are emphasized by the bankers, the VC fund managers, and the BAs (Mason, Stark 2004). The financial aspects of the proposal receive much attention by the bankers, while little emphasis is given to the market and the entrepreneur. As equity investors, the BAs and the VC fund managers stress on both market and finance issues, even though they have a very different approach. Compared to the VC fund managers, more emphasis is given to the entrepreneurs and "investor fit" considerations by the BAs. The entrepreneurs must modify their business plan in proportion to their choice: if they are looking for funding from a bank, or from BA or VC fund. Silva (2004) studied the VCs' decision-making that aimed at developing an understanding on how the VCs selected early-stage projects in small equity markets in Portugal. The findings indicated 
that the decision-making process and the criteria used by the VCs in this market context differed significantly from those used in the developed equity markets. Khanin et al. (2008) summarized the evolution of the VC investment literature from the last 4 decades. They identified the most important decision criteria of investment in new ventures as discussed in the literature, such as top management team, market, product, risk, deal, and competition. Kollmann and Kuckertz (2010) discovered that criteria relating to the management team or entrepreneur are of exceptional pertinence, but it is very difficult to assess them at the same time, particularly in the early screening phase. Accordingly, they made an important suggestion to entrepreneurs who need to be clear in mind that in order to work with the VC closely, and to reduce uncertainties, they must show preparedness, readiness, and commitment right from the beginning, as much as possible. Maxwell et al.(2011) pointed out that the BAs consider 27 criteria when making their investment decision. Only 8 critical venture factors were confirmed during the selection stage and the majority of opportunities were rejected. They also found that the investment decision was influenced by the interaction of other criteria at subsequent stages.A wide variety of possible criteria has been used by past researchers and the BAs are postulated to use them when evaluating opportunities. Table 1 summarizes the previous works published in this area of research.

\subsection{Proposed criteria}

As portrayed in Table 1, the most frequently used criteria for investment were financial considerations, market attractiveness, entrepreneurial/management team, and product/service characteristics, and specifically, the BAs' involvement activity in this research was utilized in evaluating the selection of alternatives for investment. Based upon a comprehensive literature review, five main criteria were proposed, which are briefly explained as in the following:

Financial consideration (C1): A BA may re-evaluate the balance between achieving income or capital growth caused by a change in financial situations and, as a result, the assessment of a potential investment may be affected by that. This includes 5 aspects as follows: size of investment (C11), perceived financial rewards (for investors) (C12), Clear exit opportunity (C13), potential for high returns (C14), and liquidity of investment (C15).

Market attractiveness (C2): BA investing is counted as the most important source of investment in start-up and early stage businesses looking for equity to grow their businesses. Since many BAs are investing, it may be difficult to calculate the market relatively. The market research aims to provide information about customers' demands, market size, market needs, and competition. Before pursuing a product development, market research should be conducted first. By doing this, the size of the target market can be determined, the possible sales volume, and the required unit sell price can be predicted. Hence, margin available probability or even if the product is likely to be sold at all, and if the investee business will be capable to pay back the developing cost of the product in the first place are vital details to be obtained. The sub-criteria used in this group are as follows: size of the market or niche (C21), growth potential of the market (C22), low initial cost to test the market (C23), competitive advantage (C24), low market risk (C25), and well-established distribution channel (C26). 


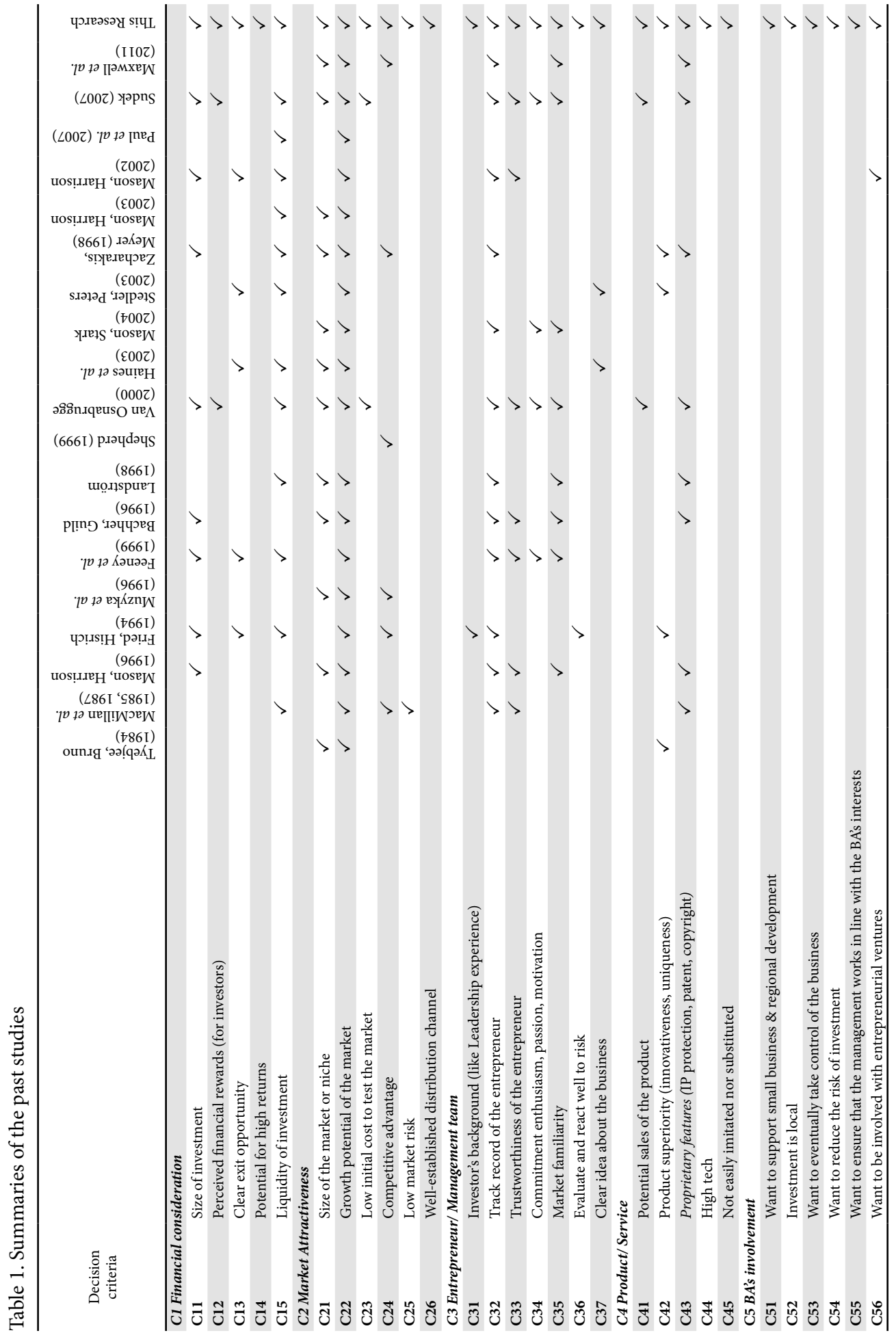




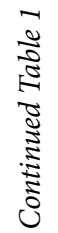

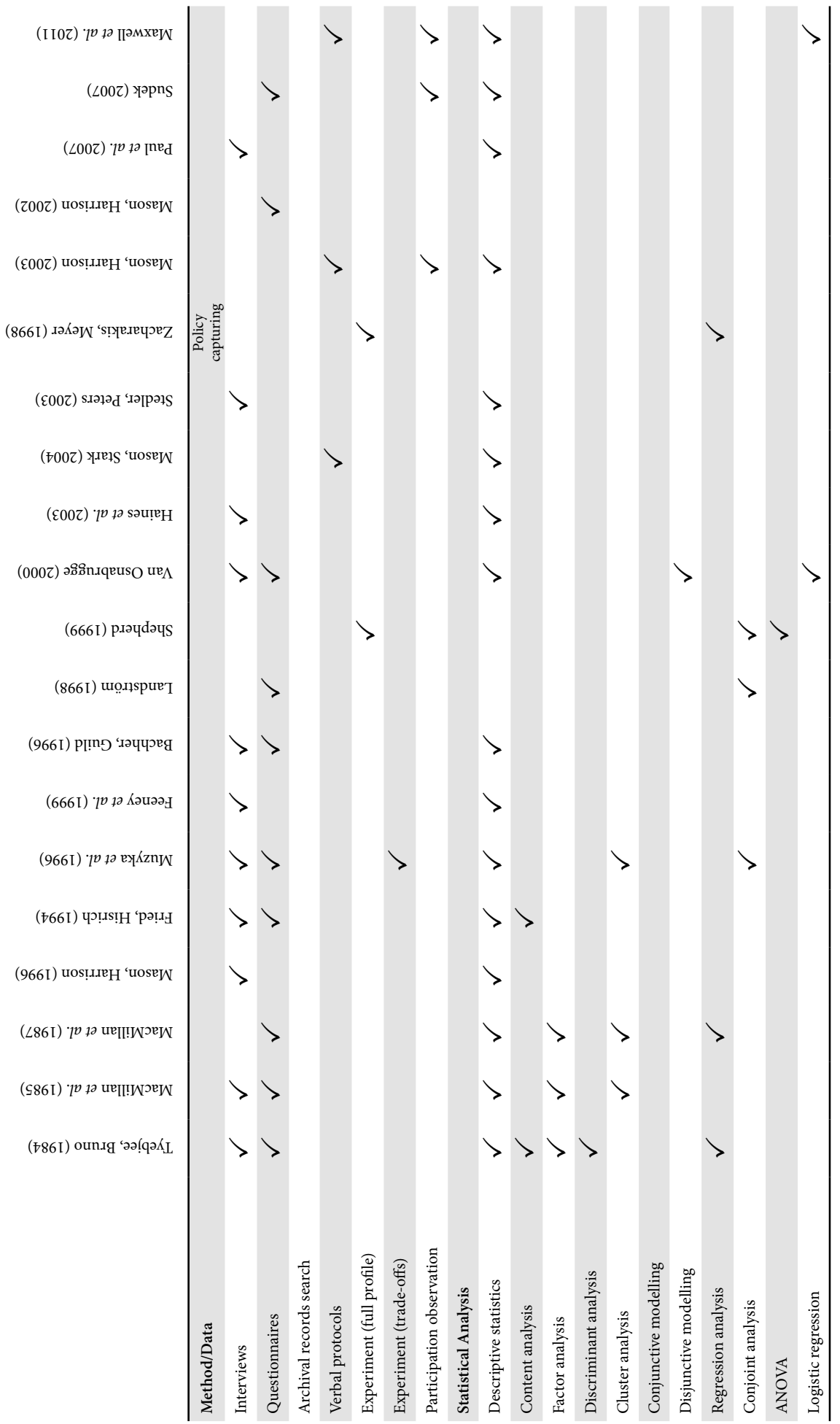


Entrepreneur/Management team (C3): The management team and entrepreneur's capacity and experience have been revealed as the most significant aspect in the start-up or early stage business for angel investors when deciding to make an investment. The quality of the management team will directly increase the chance of being successful. So, it can be a wise strategy to invest in the people, not in their product. Entrepreneurs who know their strengths, as well as their weaknesses and able to plan accordingly, are well placed to raise investment. Only a few early stage businesses have complete management teams and most of them cannot hold all the skills required to maximize their business potential. The characteristics include: Investor's background (like leadership experience) (C31), track record of the entrepreneurial (C32), trustworthiness of the entrepreneurial, commitment enthusiasm, passion, and motivation (C33), market familiarity (C34), being able to evaluate and react well to risk (C35), and have clear idea about the business (C36).

Product/Service characteristics (C4): The products characteristics are the features and elements that differentiate it from other products on the market. Characteristics of the products help to determine the marketing mix, the price of a product, and potential target market. This group includes 5 elements: potential sales of the product (C41), product superiority (innovativeness and uniqueness) (C42), proprietary features (IP protection, patent, copy right) (C43), high tech (C44), and not easily imitated nor substituted (C45).

$B A s^{\prime}$ involvement (C5): The BA's involvement in the investment venture is totally voluntary. A BA may want a lot of involvement in the business in which he invests, others may propose a business consultant or may prefer to be a mentor only. Some BAs may focus on one long term project, others may invest in several companies, or just invest in one for a short time, or in several over a period of years. In order to support a particular entrepreneur and reduce their own risk, the BAs become mainly involved in post-investment. Furthermore, the enjoyment of being related to entrepreneurial ventures in general and enjoying the involvement are strong motivational factors, whereas taking control is the least important motivator. The BAs think that their involvement in their investee companies is very active and they offer their involvement to the investee willingly. The sub-criteria of this group are as follows: supporting small business (C51), investment is local (C52), take control of the business (C53), reducing the risk (C54), to know that management works in line with BA's interests (C55), and being involved with entrepreneurial ventures (C56).

\subsection{VIKOR method}

Recently, the VIKOR method has been introduced as an applicable technique to be implemented within the MCDM. Opricovic (1998) developed the VIKOR method for multi-criteria optimization of complex systems. This method determines the compromise solution, and is able to establish the stability of decision performance by replacing the compromise solution obtained with initial weights. The compromise solution is a feasible solution, which is the closest to the ideal, and a compromise means an agreement established by mutual concessions. The VIKOR method introduces the multi-criteria ranking index based on the particular measure of "closeness" to the ideal solution and this is the main advantage of this method (Opricovic, Tzeng 2004). The obtained compromise solution provides a maximum group utility for the "majority" and a minimum individual regret for the "opponent" (Opricovic, Tzeng 2007). 
Due to its characteristics and capabilities, the application of the VIKOR method has increased in these recent years. This includes using the VIKOR in the supplier selection (Shemshadi et al. 2011; Sanayei et al. 2010; Alimardani et al. 2013), material selection (Liu et al. 2013; Girubha,Vinodh 2012), water resource planning (Opricovic 2011; Kim, Chung 2013), evaluation of buildings redevelopment (Zavadskas, Antuchevičienė 2008), forestry and renewable energy planning (Kaya, Kahraman 2010, 2011), Human resources managers competency evaluation (Liu, Wu 2012), risk evaluation (Liu et al. 2012), insurance company selection (Yücenur, Demirel 2012), customer satisfaction (Kang, Park 2014) or along with other MCDM approaches, such as AHP (Liu, Yan 2007; Wu et al. 2010; Fouladgar et al. 2012), ANP (Wang, Tzeng 2012; Ebrahimnejad et al. 2012; Yang et al. 2013), ELECTRE (Zandi, Roghanian 2013; Zavadskas et al. 2013; Kou et al. 2012), TOPSIS (Chu et al. 2007; Zhang, Wei 2013; Ju, Wang 2013; Rostamzadeh et al. 2014), COPRAS (Yazdani-Chamzini et al. 2013; Antuchevičienè et al. 2012; Aghdaie et al. 2013), SAW (Ginevičius et al. 2010; Sedaghat 2013), ARAS (Baležentis et al. 2012), DEMATEL (Hashemkhani Zolfani, Ghadikolaei 2013; Peng, Tzeng 2013), and SWARA (Zolfani et al. 2013; Hashemkhani Zolfani, Saparauskas 2013).

In this paper, the VIKOR method was applied, which was developed to evaluate the most important investment criteria from the BAs' point of view,under fuzzy environment. In the group decision-making process, linguistic variables are used by the BAs to assess the ratings and weights of the selection criteria.

\section{Fuzzy sets}

The fuzzy set theory was developed by Zadeh (1965) to solve fuzzy phenomenon problems that exist in the real world, such as uncertainty, imprecise, unspecific, and fuzzy situations. When measuring the vagueness of concepts that are related with human beings' subjective judgments, the fuzzy set theory is advantageous over the traditional set theory.

A tilde ' 's placed above a symbol if the symbol represents a fuzzy set. There are many types of fuzzy membership functions. This paper adopted the triangular fuzzy number (TFN), $\widetilde{M}$, as shown in Figure 1 . A TFN is simply denoted as $(l|m, m| u)$ or $(l, m, u)$. The smallest possible value is denoted as $l$, while $m$ is the most promising value, and $u$ is the largest possible value. Each TFN has linear representations on its left and right sides, and the function can be defined as Eq. (1):

$$
\mu(x \mid \tilde{M})=\left\{\begin{aligned}
0, & x<l, \\
\frac{x-l}{m-l}, & l \leq x \leq m, \\
\frac{u-x}{u-m}, & m \leq x \leq u, \\
0, & x>u .
\end{aligned}\right.
$$

A fuzzy number can always be given by its corresponding left and right representations of each degree of membership, as shown in Eq. (2):

$$
\widetilde{M}=M^{l(y)}, M^{r(y)}=(l+(m-l) y, u+(m-u) y), y \in[0,1] .
$$




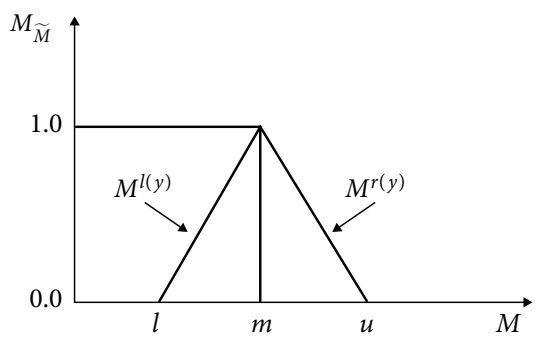

Fig. 1. Triangular fuzzy number $\widetilde{M}$

Some basic definitions of fuzzy concepts that are used in the proposed fuzzy VIKOR method are (Zadeh 1965, 1976; Zimmermann 2001) shown thereunder.

Let $\mathrm{A}=(a, b, c)$, and $\mathrm{B}=\left(a_{1}, b_{1}, c_{1}\right)$ be two triangular fuzzy numbers. The basic operations of the triangular fuzzy numbers are defined as follows:

$$
\begin{gathered}
\mathrm{A}(+) \mathrm{B}=(a, b, c)(+)\left(a_{1}, b_{1}, c_{1}\right)=\left(a+a_{1}, b+b_{1}, c+c_{1}\right) \\
\mathrm{A}(-) \mathrm{B}=(a, b, c)(-)\left(a_{1}, b_{1}, c_{1}\right)=\left(a-c_{1}, b-b_{1}, c-a_{1}\right) ; \\
\mathrm{A}(\times) \mathrm{B}=(a, b, c)(\times)\left(a_{1}, b_{1}, c_{1}\right)=\left(a a_{1}, b b_{1}, c c_{1}\right) ; \\
\mathrm{A}(\div) \mathrm{B}=(a, b, c)(\div)\left(a_{1}, b_{1}, c_{1}\right)=\left(a / c_{1}, b / b_{1}, c / a_{1}\right) ; \\
k \mathrm{~A}=(k a, k b, k c) ; \\
(\mathrm{A})^{-1}=\left(\frac{1}{c}, \frac{1}{b}, \frac{1}{a}\right) .
\end{gathered}
$$

The distance between fuzzy numbers A, B is calculated as:

$$
d(\mathrm{~A}, \mathrm{~B})=\sqrt{\frac{1}{3}\left[\left(a-a_{1}\right)^{2}+\left(b-b_{1}\right)^{2}+\left(c-c_{1}\right)^{2}\right]} .
$$

Assuming that a decision group has $K$ decision makers, and the fuzzy rating of each decision maker, $D_{k}(k=1,2, \ldots, K)$, can be represented as a positive triangular fuzzy number, $R_{k}(k=1,2, \ldots, K)$, with membership function, $F_{R K}(x)$. Then, the aggregated fuzzy rating can be defined as:

$$
R=(a, b, c), k=1,2, \ldots, K,
$$

where, $a=\min _{k}\left\{a_{k}\right\}_{k}, b=1 / k \sum_{k=1}^{K} b_{k}, c=\max _{k}\left\{c_{k}\right\}_{k}$.

The development of the VIKOR method started with the following form of Lp-metric (Opricovic 1998; Opricovic, Tzeng 2002, 2004, 2007):

$$
L_{p i}=\left\{\sum_{j=1}^{n}\left[w_{j}\left(f_{j}^{*}-f_{i j}\right) /\left(f_{j}^{*}-f_{j}^{-}\right)\right]^{p}\right\}^{1 / p} 1 \leq p \leq+\infty ; i=1,2, \ldots, I .
$$


In the VIKOR method, ( $L_{1, i}$ as $\left.S_{i}\right)$ and $\left(L_{\infty, i}\right.$ as $\left.R_{i}\right)$ are used to formulate the ranking. The solution obtained by $\min S_{i}$ is with a maximum group utility ("majority" rule), and the solution obtained by $\min R_{i}$ is with a minimum individual regret of the "opponent" (Sayadi et al. 2009). The following steps are the algorithm of the fuzzy VIKOR method using TFN:

Step 1: The objectives of the decision-making process were identified and the problem scope was defined. The objective of this research paper is to assist the BAs in investment to choose the most suitable city based on the proposed criteria.

Step 2: The decision-making group was arranged, and a finite set of relevant attributes was defined and described. As for the selection problem in this paper, there are 5 main criteria, 29 sub-criteria, and 4 different cities as alternatives. The criteria identified and analyzed in this paper can be found in the literature, as shown in Table 1.

Step 3: The appropriate linguistic variables were identified. In this step, the appropriate linguistic variables for the importance weight of criteria, and the fuzzy rating for alternatives with regard to each criterion were determined. The decision makers used the TFN linguistic variables, as shown in Table 2, to evaluate the importance of the criteria and the ratings of the alternatives with respect to qualitative criteria.

Step 4: The decision makers' opinions were taken into consideration to get the aggregated fuzzy weight of the criteria and aggregated fuzzy rating of alternatives, and then, a fuzzy decision matrix was constructed.

Table 2. Linguistic scales for importance and rating

\begin{tabular}{lll}
\hline Linguistic scale for importance & Triangular fuzzy scale & Linguistic scale for rating \\
\hline Equal & $(1,1,1)$ & Equal \\
Very Poor (VP) & $(0.1,0.1,0.2)$ & Very Low (VL) \\
Poor (P) & $(0.1,0.2,0.3)$ & Low $(\mathrm{L})$ \\
Medium Poor (MP) & $(0.3,0.4,0.5)$ & Medium Low (ML) \\
Medium (M) & $(0.4,0.5,0.6)$ & Medium (M) \\
Medium High (MH) & $(0.5,0.6,0.7)$ & Medium Good (MG) \\
High (H) & $(0.7,0.8,0.9)$ & Good (G) \\
Very High $(\mathrm{VH})$ & $(0.8,0.9,1)$ & Very Good (VG) \\
\hline
\end{tabular}

The aggregate fuzzy rating $\left(\tilde{x}_{i j}\right)$ of alternatives, with respect to each criterion, was calculated as follows:

$$
\tilde{x}_{i j}=\left(x_{i j 1}, x_{i j 2}, x_{i j 3}\right)
$$

where, $x_{i j 1}=\min \left\{x_{i j 1}\right\}_{k}, x_{i j 2}=1 / k \sum_{k}^{K} x_{i j 2}, x_{i j 3}=\max \left\{x_{i j 3}\right\}_{k}$.

And the aggregated fuzzy weights $\tilde{w}_{j}$ of each criterion can be calculated as:

$$
W=\left(\tilde{w}_{1}, \tilde{w}_{2}, \tilde{w}_{3}\right)
$$

where, $w_{j 1}=\min \left\{w_{j k 1}\right\}_{k}, w_{j 2}=1 / k \sum_{k}^{K} w_{j k 2}, w_{j 3}=\max \left\{w_{j k 3}\right\}_{k}$. 
A decision matrix, $D$, of $m \times n$ dimension is defined, as in Eq. (14):

$$
\begin{gathered}
x_{1} \\
D=A_{1}\left(\begin{array}{ccccc}
\tilde{x}_{11} & \ldots & \tilde{x}_{1 j} & \ldots & \tilde{x}_{1 n} \\
A_{i} & A_{m} \\
\tilde{x}_{i 1} & \ldots & \tilde{x}_{i j} & \ldots & \tilde{x}_{i n} \\
\tilde{x}_{m 1} & \ldots & \tilde{x}_{m j} & \ldots & \tilde{x}_{m n}
\end{array}\right),
\end{gathered}
$$

where $x_{i j}, \forall_{i j}$ may be crisp or fuzzy. If $x_{i j}$ is fuzzy, it is represented by a TFN as $\tilde{x}_{i j}=\left(a_{i j}, b_{i j}, c_{i j}\right)$. The fuzzy weights can be described by Eq. (15):

$$
W=\left(\tilde{w}_{1}, \ldots, \tilde{w}_{j}, \ldots, \tilde{w}_{n}\right) ; \tilde{w}_{j}=\left(\alpha_{j}, \beta_{j}, \chi_{j}\right) .
$$

Step 5: The fuzzy decision matrix was defuzzified and the fuzzy weight of each criterion was transformed into crisp values. In previous works, the procedure of defuzzification was performed to locate the best non-fuzzy performance (BNP) value. In general, there are 3 methods to determine the BNP value: mean of maximal (MOM), centre of area (COA), and $\alpha$-cut (Opricovic, Tzeng 2003; Chen et al. 2008). The COA method is a simple and practical method, and there is no need to introduce the preferences of any evaluators. The BNP value for COA method of triangular fuzzy performance score is $\tilde{h}_{a i}=\left(l h_{a i}, m h_{a i}, u h_{a i}\right)$, which can be calculated as follows:

$$
\mathrm{BNP}: x_{a i}=l h_{a i}+\frac{\left(u h_{a i}-l h_{a i}\right)+\left(m h_{a i}-l h_{a i}\right)}{3}, \quad \forall a \text {. }
$$

Step 6: The best $f_{j}^{*}$ and the worst $f_{j}^{-}$values for all the criterion ratings, $j=1,2, \ldots, n$, were determined.

$$
\begin{aligned}
& f_{j}^{*}=\max \left(f_{i j}\right) ; \\
& f_{j}^{-}=\min \left(f_{i j}\right),
\end{aligned}
$$

where $f_{j}^{*}$ is the positive ideal solution for the $j$ th criteria, and $f_{j}^{-}$is the negative ideal solutionfor the $j$ th criteria. If one associates all $f_{j}^{*}$, it will have the optimal combination, which will get the highest score, similar to $f_{j}^{-}$.

Step 7: The values of $S_{i}$ and $R_{i} i=1,2, \ldots, m$ were computed using Eqs (19) and (20):

$$
\begin{gathered}
S_{i}=\sum_{j=1}^{n}\left[w_{j}\left(f_{j}^{*}-f_{i j}\right) /\left(f_{j}^{*}-f_{j}^{-}\right)\right] ; \\
R_{i}=\max _{j}\left[w_{j}\left(f_{j}^{*}-f_{i j}\right) /\left(f_{j}^{*}-f_{j}^{-}\right)\right],
\end{gathered}
$$

where $S_{i}$ denotes the distance rate of $i$ th alternative to the positive ideal solution, and $R_{i}$ represents the distance rate of $i$ th alternative to the negative ideal solution. Besides, $w_{j}$ are the weights of criteria that are expressed in their relative importance. 
Step 8: The values of $Q_{i} i=1,2, \ldots, m$ were computed using Eq. (21):

$$
Q_{i}=v \frac{S_{i}-S^{*}}{S^{-}-S^{*}}+(1-v) \frac{R_{i}-R^{*}}{R^{-}-R^{*}},
$$

where $S^{-}=\max _{i} S_{i}, S^{*}=\min _{i} S_{i}, R^{-}=\max _{i} R_{i}, R^{*}=\min _{i} R_{i}$ and $v$ is the weight of the strategy of "the majority of criteria" (or "the maximum group utility"), suppose that $v=0.5$.

Step 9: The alternatives were ranked. According to the values of $Q_{i}$ that were calculated in step (8), the alternatives were ranked and the decision could be made.

Step 10: If the following 2 conditions were satisfied concurrently, then the scheme with a minimum value of $Q$ in ranking would be considered the optimal compromise solution. For example:

C1. The alternative $Q\left(\mathrm{~A}^{(1)}\right)$ has an acceptable advantage if $Q\left(\mathrm{~A}^{(2)}\right)-Q\left(\mathrm{~A}^{(1)}\right) \geq 1 / n-1$, where $\mathrm{A}^{(2)}$ is the alternative with the second position in the ranking list and $n$ is the number of alternatives.

C2. The alternative $Q\left(\mathrm{~A}^{(1)}\right)$ is stable within the decision making process if it is also best ranked in $S_{i}$ and $R_{i}$.

Step 11: The best alternative was selected by choosing $Q\left(\mathrm{~A}^{(m)}\right)$ as the best compromise solution with the minimum value of $Q_{i}$ satisfying the above conditions.

The decision makers could accept the obtained compromise solution because it provided a maximum utility of the majority (represented by $\min S$ ), and a minimum individual regret of the opponent (represented by min $R$ ). The measures of $S$ and $R$ are integrated into $Q$ for a compromise solution; the base for an agreement is established by mutual concessions. In order to summarize the methodology, the steps of the fuzzy VIKOR using the TFNs are given in the following:

Step 1: The objectives of the decision-making process were identified and the problem scope was defined.

Step 2: The decision-making group was arranged, and a finite set of relevant attributes was defined and described.

Step 3: Appropriate linguistic variables were chosen for the weights of the criteria and alternatives.

Step 4: The decision makers' opinions were taken into consideration to get the aggregated fuzzy weight of the criteria and aggregated fuzzy rating of alternatives, and then, a fuzzy decision matrix was constructed.

Step 5: The fuzzy decision matrix was defuzzified and the fuzzy weight of each criterion was transformed into crisp values.

Step 6: The best $f_{j}^{*}$ and the worst $f_{\bar{j}}$ values for all the criterion ratings were determined.

Step 7: The values of $S_{i}$ and $R_{i}$ were computed.

Step 8: The values of $Q_{i}$ were computed.

Step 9: The alternatives were ranked according to the values of $Q_{i}$.

Step 10: The decision was re-evaluated by considering satisfying of the conditions.

Step 11: The best alternative with minimum $Q_{i}$ was determined. 


\section{An application}

The role of entrepreneurs is indisputable in bringing economic changes and advancements to a country. The Malaysian government has introduced the National Innovation Model in 2007. Innovation-led growth is driven by two models; a) the technology-driven model, whereby the scientists are funded for their R\&D to develop technology originally and eventually commercialize their ideas in the global market, and b) the market-driven model, whereby the market is determined beforehand by knowledgeable entrepreneurs who acquire the best science and technology (National Survey of Innovation 2011). These will provide rapid commercialization to meet the needs of the market. Since the government's support is not enough for innovation and commercialization activities, hence, the role of BAs seems to be vital for absorbing the required funding for the commercialization activity, especially in the technology-driven model. Policy makers are willing to evaluate which region in the country has the potential for high growth to foster and speed up the commercialization process. For this reason, the 5 most well-known BAs in Malaysia were selected as the decision makers and linguistic weighting and rating variables were used to assess the importance of the criteria and to evaluate the ratings of the candidates with respect to each criterion. In the beginning, 7 cities, including Penang, Kuala Lumpur, Kota Kinabalu, Johor, Malacca, Shah Alam, and Ipoh were the candidates based on the amount of investments allocated and also on the roles that these cities play in the Gross Domestic Product (GDP). An important step in deciding on an investment is to examine and survey the economy of a country and its financial fundamentals. Different analysts need different measures, but generally, everyone considers the country's GDP, inflation, and consumer price index (CPI) readings when making an investment. Investors will also want to carefully evaluate the structure of the country's financial markets, the availability of attractive investment alternatives, and the recent performance of the local stock and the bond markets. Then, regarding the aforementioned explanations, 4 cities, including Kuala Lumpur (A1), Penang (A2), Kota Kinabalu (A3), and Johor (A4) were chosen by our experts as the alternatives to be evaluated for investment. The structure of the BAs' preferences in decision-making for investment formulated in this study is depicted in Figure 2, which includes 4 levels. The top level of the hierarchy represents the ultimate goal of the problem, while the second level consists of 5 main criteria, which are: a) financial consideration, b) market attractiveness, c) entrepreneurial and management team, d) product/service characteristics, and e) the BAs'involvement preferences. At the third level, these criteria are decomposed into various sub-criteria that may affect the BAs' choice for a particular candidate. Finally, the bottom level of the hierarchy represents the alternative cities for investment.

\section{Solution}

After determining the evaluation criteria and the alternatives, the steps of the fuzzy VIKOR algorithm were implemented as follows:

Step 1: The objectives and the structure of the research problem were identified, as shown in Table 1 and Figure 2. 


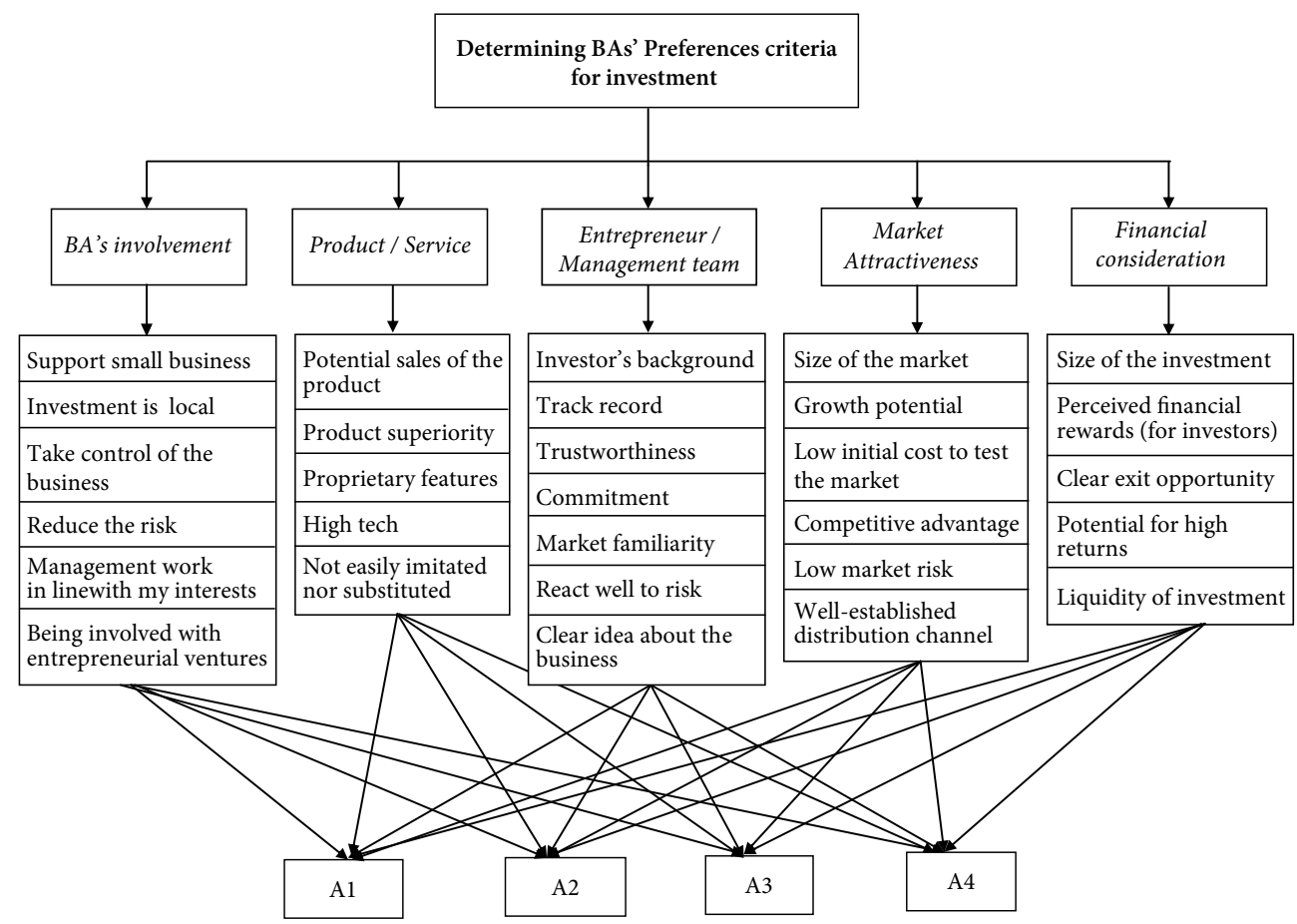

Fig. 2. Hierarchy of the problem

Step 2: In order to determine the importance of each criterion and rating of the alternatives, the experts employed a 7 point scale, as given in Table 2. Each linguistic term was associated with a triangular fuzzy number.

Step 3: The evaluation criteria, sub-criteria, and the alternatives comparisons with respect to the main criteria were drawn by the 5 decision makers correspondingly.

Step 4: The fuzzy evaluation matrix for the criteria weights and alternatives were obtained. Besides, the fuzzy values of the sub-criteria are calculated similarly. Then, using Eqs (12) and (13), the aggregated fuzzy values of the alternatives rates and subjective importance weights were calculated, as shown in Table 3.

Step 5: In this step, the aggregated fuzzy values of alternatives rates were defuzzified using Eq. (16), whereby the results are presented in Table 4.

Step 6: The best $f_{j}^{*}$ and the worst $f_{j}^{-}$were determined using Eqs (17) and (18). These values were differentiated with bold and italic font, as shown in Table 4.

Steps 7, 8, and 9: The values of $S, R$ and $Q$ for all the alternatives were calculated and summarized in Table 5 using Eqs (19-21), and the weight of the strategy for the maximum group utility $(v)$ was assumed to be 0.5 .

Step 10: The final ranking of the alternatives by $S, R$, and $Q$ in descending order were re-evaluated and shown in Table 6. Based on the crisp $Q_{i}$ index values, the ranking of the alternatives in descending order was determined as $\mathrm{A} 4>\mathrm{A} 1>\mathrm{A} 3$ and $\mathrm{A} 2$. The best alternative was found to be $\mathrm{A} 4$ (Johor). Besides, both $\mathrm{C} 1$ and $\mathrm{C} 2$ conditions were satisfied, with means $Q_{\mathrm{A} 4}-Q_{\mathrm{A} 1} \geq 1 / 4-1$, and similarly $\mathrm{A} 4$ was best ranked by $\mathrm{R}$ and $\mathrm{S}$. 
Table 3. Aggregated fuzzy values of alternatives rates and subjective importance weights

\begin{tabular}{|c|c|c|c|c|c|}
\hline & $W_{j}^{s}$ & $\mathrm{~A} 1$ & A2 & $\mathrm{A} 3$ & A4 \\
\hline $\mathrm{C} 1$ & $(0.8,0.9,1)$ & $(0.7,0.84,1)$ & $(0.6,0.78,0.9)$ & $(0.6,0.76,0.9)$ & $(0.7,0.84,1)$ \\
\hline $\mathrm{C} 2$ & $(0.6,0.76,0.9)$ & $(0.7,0.88,1)$ & $(0.7,0.86,1)$ & $(0.7,0.84,1)$ & $(0.6,0.86,1)$ \\
\hline $\mathrm{C} 3$ & $(0.7,0.86,1)$ & $(0.7,0.84,1)$ & $(0.6,0.8,1)$ & $(0.6,0.76,1)$ & $(0.6,0.78,0.9)$ \\
\hline $\mathrm{C} 4$ & $(0.35,0.62,0.8)$ & $(0.7,0.86,1)$ & $(0.7,0.82,1)$ & $(0.6,0.76,0.9)$ & $(0.7,0.82,1)$ \\
\hline C5 & $(0.6,0.76,0.9)$ & $(0.7,0.86,1)$ & $(0.7,0.86,1)$ & $(0.7,0.8,0.9)$ & $(0.6,0.74,0.9)$ \\
\hline $\mathrm{C} 11$ & $(0.6,0.74,0.9)$ & $(0.6,0.76,0.9)$ & $(0.35,0.68,0.9)$ & $(0.35,0.7,0.9)$ & $(0.35,0.64,0.9)$ \\
\hline $\mathrm{C} 12$ & $(0.2,0.46,0.65)$ & $(0.2,0.42,0.8)$ & $(0.2,0.54,0.8)$ & $(0.2,0.46,0.8)$ & $(0.2,0.38,0.65)$ \\
\hline $\mathrm{C} 13$ & $(0.2,0.38,0.65)$ & $(0.2,0.34,0.65)$ & $(0.2,0.38,0.65)$ & $(0.35,0.5,0.65)$ & $(0.35,0.66,0.8)$ \\
\hline $\mathrm{C} 14$ & $(0.8,0.9,1)$ & $(0.35,0.54,0.8)$ & $(0.6,0.7,0.8)$ & $(0.6,0.76,0.9)$ & $(0.6,0.76,0.9)$ \\
\hline $\mathrm{C} 15$ & $(0.6,0.76,0.9)$ & $(0.35,0.58,0.8)$ & $(0.35,0.58,0.8)$ & $(0.6,0.72,0.9)$ & $(0.6,0.72,0.9)$ \\
\hline $\mathrm{C} 21$ & $(0.6,0.72,0.9)$ & $(0.35,0.64,0.9)$ & $(0.35,0.66,0.9)$ & $(0.35,0.7,0.9)$ & $(0.6,0.74,0.9)$ \\
\hline $\mathrm{C} 22$ & $(0.7,0.86,1)$ & $(0.6,0.74,0.9)$ & $(0.35,0.7,0.9)$ & $(0.6,0.74,0.9)$ & $(0.6,0.8,1)$ \\
\hline $\mathrm{C} 23$ & $(0.35,0.68,0.9)$ & $(0.2,0.44,0.65)$ & $(0.2,0.46,0.65)$ & $(0.2,0.42,0.65)$ & $(0.2,0.34,0.65)$ \\
\hline $\mathrm{C} 24$ & $(0.6,0.78,0.9)$ & $(0.2,0.54,0.8)$ & $(0.2,0.58,0.8)$ & $(0.35,0.54,0.8)$ & $(0.2,0.58,0.8)$ \\
\hline $\mathrm{C} 25$ & $(0.6,0.8,1)$ & $(0.2,0.46,0.8)$ & $(0.2,0.54,0.8)$ & $(0.2,0.42,0.65)$ & $(0.2,0.34,0.65)$ \\
\hline $\mathrm{C} 26$ & $(0.7,0.84,1)$ & $(0.35,0.62,0.9)$ & $(0.35,0.62,0.8)$ & $(0.6,0.76,0.9)$ & $(0.35,0.72,0.9)$ \\
\hline C31 & $(0.7,0.86,1)$ & $(0.6,0.7,0.8)$ & $(0.6,0.72,0.9)$ & $(0.6,0.7,0.8)$ & $(0.6,0.78,0.9)$ \\
\hline $\mathrm{C} 32$ & $(0.8,0.9,1)$ & $(0.35,0.62,0.8)$ & $(0.35,0.62,0.8)$ & $(0.6,0.7,0.8)$ & $(0.6,0.74,0.9)$ \\
\hline C33 & $(0.7,0.86,1)$ & $(0.35,0.66,0.8)$ & $(0.35,0.68,0.8)$ & $(0.35,0.66,0.8)$ & $(0.6,0.76,0.9)$ \\
\hline $\mathrm{C} 34$ & $(0.7,0.82,1)$ & $(0.35,0.5,0.65)$ & $(0.35,0.66,0.8)$ & $(0.35,0.66,0.8)$ & $(0.35,0.78,1)$ \\
\hline $\mathrm{C} 35$ & $(0.6,0.76,0.9)$ & $(0.6,0.82,1)$ & $(0.6,0.76,0.9)$ & $(0.6,0.78,0.9)$ & $(0.7,0.84,1)$ \\
\hline $\mathrm{C} 36$ & $(0.7,0.86,1)$ & $(0.6,0.82,1)$ & $(0.7,0.82,1)$ & $(0.7,0.82,1)$ & $(0.7,0.86,1)$ \\
\hline C37 & $(0.6,0.76,0.9)$ & $(0.35,0.58,0.8)$ & $(0.2,0.58,0.8)$ & $(0.35,0.58,0.8)$ & $(0.35,0.66,0.8)$ \\
\hline C41 & $(0.7,0.86,1)$ & $(0.6,0.78,0.9)$ & $(0.7,0.82,1)$ & $(0.6,0.8,1)$ & $(0.7,0.82,1)$ \\
\hline $\mathrm{C} 42$ & $(0.7,0.8,0.9)$ & $(0.35,0.68,0.9)$ & $(0.6,0.72,0.9)$ & $(0.6,0.7,0.8)$ & $(0.6,0.78,1)$ \\
\hline $\mathrm{C} 43$ & $(0.7,0.86,1)$ & $(0.35,0.6,0.9)$ & $(0.2,0.48,0.9)$ & $(0.6,0.7,0.8)$ & $(0.35,0.64,0.9)$ \\
\hline $\mathrm{C} 44$ & $(0.2,0.46,0.8)$ & $(0.2,0.42,0.65)$ & $(0.2,0.38,0.65)$ & $(0.2,0.5,0.8)$ & $(0.2,0.42,0.8)$ \\
\hline C45 & $(0.6,0.74,0.9)$ & $(0.2,0.34,0.65)$ & $(0.2,0.46,0.8)$ & $(0.35,0.62,0.8)$ & $(0.2,0.5,0.8)$ \\
\hline C51 & $(0.7,0.84,1)$ & $(0.35,0.62,0.8)$ & $(0.2,0.5,0.8)$ & $(0.6,0.7,0.8)$ & $(0.6,0.74,0.9)$ \\
\hline C52 & $(0.6,0.74,0.9)$ & $(0.2,0.5,0.8)$ & $(0.2,0.5,0.8)$ & $(0.2,0.58,0.8)$ & $(0.2,0.54,0.8)$ \\
\hline C53 & $(0.7,0.86,1)$ & $(0.35,0.66,0.9)$ & $(0.350 .7,0.9)$ & $(0.6,0.72,0.9)$ & $(0.35,0.68,0.9)$ \\
\hline C54 & $(0.7,0.82,1)$ & $(0.6,0.78,0.9)$ & $(0.35,0.64,0.9)$ & $(0.35,0.66,0.8)$ & $(0.6,0.72,0.9)$ \\
\hline C55 & $(0.6,0.76,0.9)$ & $(0.35,0.72,1)$ & $(0.6,0.72,0.9)$ & $(0.6,0.76,0.9)$ & $(0.6,0.78,1)$ \\
\hline C56 & $(0.7,0.84,1)$ & $(0.6,0.76,1)$ & $(0.6,0.76,0.9)$ & $(0.6,0.78,1)$ & $(0.6,0.82,1)$ \\
\hline
\end{tabular}


Table 4. Defuzzyfied aggregated fuzzy values of the cities' rates

\begin{tabular}{|c|c|c|c|c|c|c|}
\hline & $W_{j}^{s}$ & Normalized $W_{j}^{s}$ & A1 & A2 & A3 & A4 \\
\hline $\mathrm{C} 1$ & $(0.9)$ & $(0.234)$ & $(0.846)$ & $(0.76)$ & $(0.753)$ & $(0.846)$ \\
\hline $\mathrm{C} 2$ & $(0.753)$ & $(0.195)$ & $(0.86)$ & $(0.853)$ & $(0.846)$ & $(0.82)$ \\
\hline $\mathrm{C} 3$ & $(0.853)$ & $(0.221)$ & $(0.846)$ & $(0.8)$ & $(0.786)$ & $(0.76)$ \\
\hline $\mathrm{C} 4$ & $(0.59)$ & $(0.153)$ & $(0.853)$ & $(0.84)$ & $(0.753)$ & $(0.84)$ \\
\hline C5 & $(0.753)$ & $(0.195)$ & $(0.853)$ & $(0.853)$ & $(0.8)$ & $(0.746)$ \\
\hline $\mathrm{C} 11$ & $(0.746)$ & $(0.229)$ & $(0.753)$ & $(0.643)$ & $(0.65)$ & $(0.63)$ \\
\hline $\mathrm{C} 12$ & $(0.436)$ & $(0.134)$ & $(0.473)$ & $(0.513)$ & $(0.486)$ & $(0.41)$ \\
\hline $\mathrm{C} 13$ & $(0.41)$ & $(0.126)$ & $(0.396)$ & $(0.41)$ & $(0.5)$ & $(0.603)$ \\
\hline $\mathrm{C} 14$ & $(0.9)$ & $(0.277)$ & $(0.563)$ & $(0.7)$ & $(0.753)$ & $(0.753)$ \\
\hline $\mathrm{C} 15$ & $(0.753)$ & $(0.232)$ & $(0.576)$ & $(0.576)$ & $(0.74)$ & $(0.74)$ \\
\hline $\mathrm{C} 21$ & $(0.74)$ & $(0.159)$ & $(0.63)$ & $(0.636)$ & $(0.65)$ & $(0.746)$ \\
\hline $\mathrm{C} 22$ & $(0.853)$ & $(0.183)$ & $(0.746)$ & $(0.65)$ & $(0.746)$ & $(0.8)$ \\
\hline $\mathrm{C} 23$ & $(0.643)$ & $(0.138)$ & $(0.43)$ & $(0.436)$ & $(0.423)$ & $(0.396)$ \\
\hline $\mathrm{C} 24$ & $(0.76)$ & $(0.163)$ & $(0.513)$ & $(0.526)$ & $(0.563)$ & $(0.526)$ \\
\hline $\mathrm{C} 25$ & $(0.8)$ & $(0.172)$ & $(0.486)$ & $(0.513)$ & $(0.423)$ & $(0.396)$ \\
\hline $\mathrm{C} 26$ & $(0.846)$ & $(0.182)$ & $(0.623)$ & $(0.59)$ & $(0.7)$ & $(0.753)$ \\
\hline $\mathrm{C} 31$ & $(0.853)$ & $(0.147)$ & $(0.7)$ & $(0.74)$ & $(0.7)$ & $(0.76)$ \\
\hline C32 & $(0.9)$ & $(0.155)$ & $(0.59)$ & $(0.59)$ & (0.7) & $(0.746)$ \\
\hline C33 & $(0.846)$ & $(0.145)$ & $(0.603)$ & $(0.61)$ & $(0.603)$ & $(0.753)$ \\
\hline C34 & $(0.84)$ & $(0.144)$ & (0.5) & $(0.603)$ & $(0.603)$ & $(0.71)$ \\
\hline C35 & $(0.753)$ & $(0.129)$ & $(0.806)$ & (0.753) & $(0.76)$ & $(0.846)$ \\
\hline C36 & $(0.846)$ & $(0.145)$ & $(0.806)$ & $(0.84)$ & $(0.84)$ & $(0.853)$ \\
\hline C37 & $(0.753)$ & (0.129) & $(0.576)$ & $(0.526)$ & $(0.576)$ & $(0.603)$ \\
\hline C41 & $(0.846)$ & $(0.226)$ & $(0.76)$ & $(0.84)$ & $(0.8)$ & $(0.84)$ \\
\hline $\mathrm{C} 42$ & $(0.8)$ & $(0.214)$ & (0.643) & $(0.74)$ & (0.7) & $(0.793)$ \\
\hline C43 & $(0.853)$ & $(0.23)$ & $(0.616)$ & $(0.526)$ & $(0.7)$ & $(0.63)$ \\
\hline C44 & $(0.486)$ & $(0.131)$ & $(0.423)$ & $(0.41)$ & $(0.5)$ & $(0.473)$ \\
\hline C45 & $(0.746)$ & $(0.201)$ & $(0.396)$ & $(0.486)$ & $(0.59)$ & $(0.5)$ \\
\hline C51 & $(0.846)$ & $(0.173)$ & $(0.59)$ & (0.5) & $(0.7)$ & $(0.746)$ \\
\hline C52 & $(0.746)$ & $(0.152)$ & (0.5) & (0.5) & $(0.526)$ & $(0.513)$ \\
\hline C53 & $(0.853)$ & $(0.174)$ & $(0.636)$ & $(0.65)$ & $(0.74)$ & $(0.643)$ \\
\hline C54 & $(0.84)$ & $(0.172)$ & $(0.76)$ & (0.63) & (0.603) & $(0.74)$ \\
\hline C55 & $(0.753)$ & $(0.154)$ & $(0.69)$ & $(0.74)$ & $(0.753)$ & $(0.793)$ \\
\hline C56 & $(0.846)$ & $(0.173)$ & $(0.786)$ & (0.753) & $(0.793)$ & $(0.806)$ \\
\hline
\end{tabular}

Step 11: A4 was the best selected city for the best compromise solution. The subsequent rank order went to Kuala Lumpur, Penang, and Sabah.

Using Eqs (17) and (18), the values of $S_{i}$ and $R_{i}$ are computed in Table 5.

Table 5. The values of $\mathrm{S}$ and $\mathrm{R}$ for all the states

\begin{tabular}{ccccccc}
\hline Firm & $S$ & $R$ & & & & $Q$ \\
\hline A1 & 3.66 & 0.02 & & $S_{j}^{*}=1.888$ & $R_{j}^{*}=0.019$ & 0.503 \\
A2 & 3.773 & 0.034 & & & & 1 \\
A3 & 2.585 & 0.032 & & $S_{j}^{-}=3.773 \quad R_{j}^{-}=0.034$ & 0.617 \\
A4 & 1.888 & 0.019 & & & 0 \\
\hline
\end{tabular}


Using Eq. (19), the values of $Q_{i}$ are computed as shown in Table 6 .

Table 6. The ranking of the states by $\mathrm{S}, \mathrm{R}$, and $\mathrm{Q}$ in descending order

\begin{tabular}{cccccc}
\hline \multicolumn{2}{c}{$Q$} & \multicolumn{2}{c}{$R$} & \multicolumn{2}{c}{$S$} \\
\hline A4 & 0 & A4 & 0.019 & A4 & 1.888 \\
A1 & 0.503 & A1 & 0.02 & A3 & 2.585 \\
A3 & 0.617 & A3 & 0.032 & A1 & 3.66 \\
A2 & 1 & A2 & 0.034 & A2 & 3.773 \\
\hline
\end{tabular}

\section{Managerial implications}

This paper applied the BAs' preferences to evaluate the most potential city for investment using the VIKOR method extended under fuzzy environment. The results showed that Johor is the best city for investment. Besides, based on the normalized weights achieved from Table 4, the main criteria and sub-criteria were ranked as follows: financial consideration (C1) width (0.234) placed as the first priority, management and entrepreneurial team (C3) width (0.221) in the second place, both market attractiveness (C2) and the BAs' involvement (C5) width (0.195) sharing the same place, and product/service characteristics (C4) with (0.153) that acquired the lowest importance. In financial consideration group, the potential for high returns (C14) was placed in the first rank width (0.277), and clear exit opportunity (C13) received the lowest rank width (0.126). In market attractiveness group, growth potential of the market or niche (C22) obtained the first rank width (0.183) and low initial cost to test the market (C23) was in the last place width (0.138). In management and entrepreneurial, track record (C32) received the first rank width (0.155), and market familiarity (C35) and clear idea about the business (C37) earned the same rank width (0.129). In product group, proprietary features (IP protection, patent, copyright) (C43) were placed in the first rank width (0.23), and high tech (C44) width (0.131) was placed in the last rank. In involving preferences of the BAs group, taking control of the business (C53) was placed in the first rank width (0.174), and local investment (C52) received the lowest importance width (0.152).

Angel investment trends, the organization of angel investing, and the types of investments made by angels have significance for policy-makers seeking to support business start-up and growth. Investments have been made in various industries, including e-commerce, fashion, communication, services, and business-to-business enterprises. In addition to funding, angel investors are mentoring the start-ups, and giving them access to business networks to help them realize their full potential. Access to external capital is difficult for investors seeking entrepreneurial ventures in many countries worldwide, and a shortage of risk capital is one of the greatest hurdles for entrepreneurs when starting up a new company, particularly in hightech and high-growth business areas. Although knowledge of the Malaysian situation is less complete, it is likely that in this country as well, angel investors are a very important source of capital for early-stage businesses. In addition, investing in early-stage (i.e. seed and start-up) and early-growth ventures is not easy, as obtaining financing is the most difficult task for an entrepreneur during these stages, and accordingly, knowing about the potential investors and 
their investment criteria is most crucial. Furthermore, the selection criteria are different from those used to evaluate the later-stage. Therefore, regarding the later-stage investments, for example, accounting information plays an important role for valuation purposes, whereas such information is usually not available for earlier investment projects. In these cases, more intangible information, like the quality of the management team or product and market characteristics are involved for evaluation (Manigart et al. 1998). Furthermore, Riding et al. (1997) found that the importance of investors' decision criteria depends on the stage of decision process and it may differ from one stage to another. For example, the importance of the criteria during the "first impressions" stage possibly varies from the importance of the same criteria the point when negotiations are undertaken. These shortcomings point the way for future research.

\section{Conclusions}

The MCDM method has high potential to reduce cost and time, as well as increase the accuracy of decisions and canals and can be an appropriate framework for solving problems. This paper applied the BAs' preferences to evaluate and select the city with the highest potential for investment using the VIKOR method extended under fuzzy environment. For this reason, the 5 most well-known business angels in Malaysia were selected as decision makers, using the linguistic weighting and rating variables to assess the importance of the criteria and to evaluate the ratings of candidates with respect to each criterion. Then, 5 main criteria and 29 sub-criteria were proposed for the evaluation of the alternatives. A selection was made using the fuzzy VIKOR. In the fuzzy VIKOR, linguistic evaluations of the experts were easily converted to fuzzy numbers, which were used in calculations. The results of the multi-criteria decision analysis suggested that Johor is the best alternative for investment in the country. The ranking of the alternatives in descending order is Kuala Lumpur, Penang, and Sabah. Besides selection problem, the results also indicated the 5 dominant sub-criteria in each group: potential for high returns, growth potential of the market or niche, track record of entrepreneurial, proprietary features (IP protection, patent, and copyright), and taking control of the business.

Even though the proposed methodology was successfully applied for decision making problems, limitations do exist due to the limited access to the BAs as most of them have a tendency to maintain a low public profile. Thus, only five BAs were chosen for this study. Future studies could involve more BAs in the decision making process, which will enhance the reliability of the proposed framework. The extensive literature provided in this research could be used for further analysis using different techniques like explanatory factor analysis (EFA) and structural equation modelling (SEM). However, recognizing these also forms the basis for future work. Another shortcoming of this research is that only the VIKOR method was used in the fuzzy environment because no previous researches have applied this method for the evaluation of the BAs' preferences in investment decision making. From the methodological perspective, it would be helpful to consider alternative methodological approaches to test the proposed framework. A comparative analysis based on different MCDM techniques, such as fuzzy ELECTRE, fuzzy PROMETHEE or fuzzy TOPSIS can be conducted. The results obtained from these methods can be compared with the results obtained from this work, which can be used as an outline for future research. 


\section{Acknowledgments}

This research is conducted under the postdoctoral program of Universiti Teknologi Malaysia (UTM). The authors are grateful to the Research Management Centre (RMC) for their generous support with this research.

\section{References}

Aghdaie, M. H.; Zolfani, S. H.; Zavadskas, E. K. 2013. Market segment evaluation and selection based on application of fuzzy AHP and COPRAS-G methods, Journal of Business Economics and Management 14(1): 213-233. http://dx.doi.org/10.3846/16111699.2012.721392

Alimardani, M.; Zolfani, S. H.; Aghdaie, M. H.; Tamošaitienė, J. 2013. A novel hybrid SWARA and VIKOR methodology for supplier selection in an agile environment, Technological and Economic Development of Economy19(3): 533-548. http://dx.doi.org/10.3846/20294913.2013.814606

Antuchevičienė, J.; Zavadskas, E. K.; Zakarevičius, A. 2012. Ranking redevelopment decisions of derelict buildings and analysis of ranking results, Journal of Economic Computation and Economic Cybernetics Studies and Research (ECECSR) 46(2): 37-62. Bucharest: Academy of Economic Studies.

Bachher, J. S.; Guild, P. D. 1996. Financing early stage technology based companies: investment criteria used by investors, in P. D. Reynolds, W. D. Bygrave, J. E. Butler, S. Birley, P. Davidsson (Eds). Frontiers of Entrepreneurship Research: Proceedings of the 16th Annual Entrepreneurship Research Conference, Babson College, Wellesley, MA, 363-376.

Baležentis, A.; Baležentis, T.; Misiunas, A. 2012. An integrated assessment of Lithuanian economic sectors based on financial ratios and fuzzy MCDM methods, Technological and Economic Development of Economy 18(1): 34-53. http://dx.doi.org/10.3846/20294913.2012.656151

Chen, M. F.; Tzeng, G. H.; Ding, C. G. 2008. Combining fuzzy AHP with MDS in identifying the preference similarity of alternatives, Applied Soft Computing 8(1): 110-117. http://dx.doi.org/10.1016/j.asoc.2006.11.007

Chu, M. T.; Shyu, J.; Tzeng, G. H.; Khosla, R. 2007. Comparison among three analytical methods for knowledge communities group-decision analysis, Expert Systems with Applications 33(4): 1011-1024. http://dx.doi.org/10.1016/j.eswa.2006.08.026

Ebrahimnejad, S.; Mousavi, S. M.; Tavakkoli-Moghaddam, R.; Hashemi, H.; Vahdani, B. 2012. A novel two-phase group decision making approach for construction project selection in a fuzzy environment, Applied Mathematical Modelling 36(9): 4197-4217. http://dx.doi.org/10.1016/j.apm.2011.11.050

Feeney, L.; Haines, G. H.; Riding, A. L. 1999. Private investors' investment criteria: insights from qualitative data, Venture Capital: an International Journal of Entrepreneurial Finance 1(2): 121-145. http://dx.doi.org/10.1080/136910699295938

Fouladgar, M. M.; Yazdani-Chamzini, A.; Zavadskas, E. K.; Yakhchali, S. H.; Ghasempourabadi, M. H. 2012. Project portfolio selection using Fuzzy AHP and VIKOR techniques, Transformations in Business \& Economics 11(1): 213-231.

Fried, V. H.; Hisrich, R. D. 1994. Toward a model of venture capital investment decision making, Financial Management 23(3): 28-37. http://dx.doi.org/10.2307/3665619

Ginevičius, R.; Krivka, A.; Šimkūnaite, J. 2010. The model of forming competitive strategy of an enterprise under the conditions of oligopolic market, Journal of Business Economics and Management 11(3): 367-395. http://dx.doi.org/10.3846/jbem.2010.18

Girubha, J. R.; Vinodh, S. 2012. Application of fuzzy VIKOR and environmental impact analysis for material selection of an automotive component, Materials \& Design 37: 478-486.

http://dx.doi.org/10.1016/j.matdes.2012.01.022 
Gullander, S.; Napier, G. 2003. Handbook in business angel networks -the Nordic case. Stockholm School of Entrepreneurship.

Haines, G. H. Jr.; Madill, J. J.; Riding, A. R. 2003. Informal investment in Canada: financing small business growth, Journal of Small Business and Entrepreneurship 16(3-4): 13-40. http://dx.doi.org/10.1080/08276331.2003.10593306

Hajiagha, S. H. R.; Hashemi, S. S.; Zavadskas, E. K. 2013. A complex proportional assessment method for group decision making in an interval-valued intuitionistic fuzzy environment, Technological and Economic Development of Economy 19(1): 22-37. http://dx.doi.org/10.3846/20294913.2012.762953

Hall, J.; Hofer, C. W.1993. Venture capitalists' decision criteria in new venture evaluation, Journal of Business Venturing 8(1): 25-42. http://dx.doi.org/10.1016/0883-9026(93)90009-T

Hashemkhani Zolfani, S. H.; Saparauskas, J. 2013. New application of SWARA method in prioritizing sustainability assessment indicators of energy system, Inzinerine ekonomika - Engineering Economics 24(5): 408-414.

Hashemkhani Zolfani, S.; Ghadikolaei, S. A. 2013. Performance evaluation of private universities based on balanced scorecard: empirical study based on Iran, Journal of Business Economics and Management 14(4): 696-714. http://dx.doi.org/10.3846/16111699.2012.665383

Jin, F.; Liu, P.; Zhang, X. 2013. The multi-attribute group decision making method based on the interval grey linguistic variables weighted harmonic aggregation operators, Technological and Economic Development of Economy 19(3): 409-430. http://dx.doi.org/10.3846/20294913.2013.821685

Ju, Y.; Wang, A. 2013. Extension of VIKOR method for multi-criteria group decision making problem with linguistic information, Applied Mathematical Modelling 37(5): 3112-3125. http://dx.doi.org/10.1016/j.apm.2012.07.035

Kang, D.; Park, Y. 2014. Review-based measurement of customer satisfaction in mobile service: sentiment analysis and VIKOR approach, Expert Systems with Applications 41(4): 1041-1050. http://dx.doi.org/10.1016/j.eswa.2013.07.101

Kaya, T.; Kahraman, C. 2010. Multicriteria renewable energy planning using an integrated fuzzy VIKOR \& AHP methodology: the case of Istanbul, Energy 35(6): 2517-2527. http://dx.doi.org/10.1016/j.energy.2010.02.051

Kaya, T.; Kahraman, C. 2011. Fuzzy multiple criteria forestry decision making based on an integrated VIKOR and AHP approach, Expert Systems with Applications 38(6): 7326-7333. http://dx.doi.org/10.1016/j.eswa.2010.12.003

Khanin, D.; Baum, J. R.; Mahto, R. V.; Heller, C. 2008. Venture capitalists' investment criteria: 40 years of research, Small Business Institute ${ }^{\circledast}$ Research Review 35: 187-192.

Kim, Y.; Chung, E. S. 2013. Fuzzy VIKOR approach for assessing the vulnerability of the water supply to climate change and variability in South Korea, Applied Mathematical Modelling 37(22): 9419-9430. http://dx.doi.org/10.1016/j.apm.2013.04.040

Kollmann, T.; Kuckertz, A. 2010. Evaluation uncertainty of venture capitalists' investment criteria, Journal of Business Research 63(7): 741-747. http://dx.doi.org/10.1016/j.jbusres.2009.06.004

Kou, G.; Lu, Y.; Peng, Y.; Shi, Y. 2012. Evaluation of classification algorithms using MCDM and rank correlation, International Journal of Information Technology \& Decision Making 11(1): 197-225. http://dx.doi.org/10.1142/S0219622012500095

Kumar, V.; Kaura, N. M. 2003. Venture capitalists' screening criteria,VIKALPA 28(2): 49-59.

Landström, H. 1998. Informal investors as entrepreneurs, Technovation 18(5): 321-333. http://dx.doi.org/10.1016/S0166-4972(98)00001-7

Liu, P.; Yu, X. 2013. Density aggregation operators based on the intuitionistic trapezoidal fuzzy numbers for multiple attribute decision making, Technological and Economic Development of Economy 19(sup1): S454-S470. 
Liu, H. C.; Liu, L.; Liu, N.; Mao, L. X. 2012. Risk evaluation in failure mode and effects analysis with extended VIKOR method under fuzzy environment, Expert Systems with Applications 39(17): 12926-12934. http://dx.doi.org/10.1016/j.eswa.2012.05.031

Liu, H. C.; Mao, L. X.; Zhang, Z. Y.; Li, P. 2013. Induced aggregation operators in the VIKOR method and its application in material selection, Applied Mathematical Modelling 37(9): 6325-6338. http://dx.doi.org/10.1016/j.apm.2013.01.026

Liu, H.; Yan, T. 2007. Bidding-evaluation of construction projects based on VIKOR method, in Proceedings of the IEEE International Conference on Automation and Logistics, 18-21 August 2007, Jinan, 1778-1782.

Liu, P.; Wu, X. 2012. A competency evaluation method of human resources managers based on multi-granularity linguistic variables and VIKOR method, Technological and Economic Development of Economy 18(4): 696-710. http://dx.doi.org/10.3846/20294913.2012.753169

Macmillan, I. C.; Siegel, R.; Narasimha, S. P. N. 1985. Criteria used by venture capitalists to evaluate new venture proposals, Journal of Business Venturing 1(1): 119-128.

http://dx.doi.org/10.1016/0883-9026(85)90011-4

Macmillan, I. C.; Zemann, L.; Narsimha, S. P. N. 1987. Criteria distinguishing successful from unsuccessful ventures screening process, Journal of Business Venturing 2(2): 123-137. http://dx.doi.org/10.1016/0883-9026(87)90003-6

Manigart, S.; Wright, M.; Robbie, K.; Desbrière, P.; De Waele, K. 1998. Venture capitalists' appraisal of investment projects: an empirical European study, Entrepreneurship Theory and Practice 21(4): 29-43.

Mason, C. M.; Harrison, R. T. 1996. Why business angels' say no: a case study of opportunities rejected by an informal investor, International Small Business Journal 14 (2): 35-51. http://dx.doi.org/10.1177/0266242696142003

Mason, C. M.; Harrison, R. T. 2002. Is it worth it? The rates of return from informal venture capital investments, Journal of Business Venturing 17(13): 211-236.

http://dx.doi.org/10.1016/S0883-9026(00)00060-4

Mason, C. M.; Harrison, R. T. 2003. Auditioning for money: what do technology investors look for at the initial screening stage?, Journal of Private Equity 6(2): 29-42. http://dx.doi.org/10.3905/jpe.2003.320037

Mason, C. M.; Rogers, A. 1997. The business angel's investment decision: an exploratory analysis, in D. Deakins, P. Jennings, C. Mason (Eds.). Entrepreneurship in the 1990s. London: Paul Chapman Publishing, 29-46.

Mason, C. M.; Stark, M. 2004. What do investors look for in a business plan? A comparison of the investment criteria of bankers, venture capitalists and business angels, International Small Business Journal 22(3): 227-248. http://dx.doi.org/10.1177/0266242604042377

Maxwell, A. L.; Jeffrey, S. A.; Lévesque, M. 2011 .Business angel decision-making, Journal of Business Venturing 26(2): 212-225. http://dx.doi.org/10.1016/j.jbusvent.2009.09.002

Muzyka, D.; Birley, S.; Leleux, B. 1996. Trade-offs in the investment decisions of European venture capitalists, Journal of Business Venturing 11(4): 273-287. http://dx.doi.org/10.1016/0883-9026(95)00126-3

National Survey of Innovation. 2011. Malaysian Science and Technology Information Centre (MASTIC), Ministry of Science, Technology and Innovation (MOSTI).

Opricovic, S. 1998. Multicriteria optimization of civil engineering systems. Faculty of Civil Engineering Belgrade, Belgrade.

Opricovic, S. 2011. Fuzzy VIKOR with an application to water resources planning, Expert Systems with Applications 38(10):12983-12990. http://dx.doi.org/10.1016/j.eswa.2011.04.097

Opricovic, S.; Tzeng, G. H. 2002. Multicriteria planning of post-earthquake sustainable reconstruction, Computer-Aided Civil and Infrastructure Engineering 17(3): 211-220.

http://dx.doi.org/10.1111/1467-8667.00269 
Opricovic, S.; Tzeng, G. H. 2003. Defuzzification for a multicriteria decision making model, International Journal of Uncertainty, Fuzziness and Knowledge-Based Systems 11(5): 635-652. http://dx.doi.org/10.1142/S0218488503002387

Opricovic, S.; Tzeng, G. H. 2004. Compromise solution by MCDM methods: a comparative analysis of VIKOR and TOPSIS, European Journal of Operational Research 156(2): 445-455. http://dx.doi.org/10.1016/S0377-2217(03)00020-1

Opricovic, S.; Tzeng, G. H. 2007. Extended VIKOR method in comparison with outranking methods, European Journal of Operational Research 178(2): 514-529. http://dx.doi.org/10.1016/j.ejor.2006.01.020

Paul, S.; Whittam, G.;Wyper, J. 2007. Towards a model of the business angel investment process, Venture Capital 9(2): 107-125. http://dx.doi.org/10.1080/13691060601185425

Peng, K. H.; Tzeng, G. H. 2013. A hybrid dynamic MADM model for problem-improvement in economics and business, Technological and Economic Development of Economy 19(4): 638-660.

http://dx.doi.org/10.3846/20294913.2013.837114

Riding, A.; Duxbury, L.; Haines, G. J. 1997. Financing enterprise development: decision-making by Canadian angels, Conference Proceedings for the Entrepreneurship Division of the Association of Management and International Association of Management, August 1997, 17-22.

Rostamzadeh, R.; Ismail, K.; Nobar, H. B. K. 2014. An application of a hybrid MCDM method for the evaluation of entrepreneurial intensity among the SMEs: a case study, The Scientific World Journal, Volume 2014, Article ID 703650, 16 p. http://dx.doi.org/10.1155/2014/703650

Sanayei, A.; Mousavi, S. F.; Yazdankhah, A. 2010. Group decision making process for supplier selection with VIKOR under fuzzy environment, Expert Systems with Applications 37(1): 24-30. http://dx.doi.org/10.1016/j.eswa.2009.04.063

Sayadi, M. K.; Heydari, M.; Shahanaghi, K. 2009. Extension of VIKOR method for decision making problem with interval numbers, Applied Mathematical Modelling 33(5): 2257-2262. http://dx.doi.org/10.1016/j.apm.2008.06.002

Sedaghat, M. 2013. A productivity improvement evaluation model by integrating AHP, TOPSIS and VIKOR methods under fuzzy environment, Economic Computation and Economic Cybernetics Studies and Research 47(1): 235-258.

Schwarzkopf, J.; Lévesque, M.; Maxwell, A. 2010. How entrepreneurs-in-residence increase seed investment rates, Venture Capital 12(1): 65-81. http://dx.doi.org/10.1080/13691060903435783

Shemshadi, A.; Shirazi, H.; Toreihi, M.; Tarokh, M. J. 2011. A fuzzy VIKOR method for supplier selection based on entropy measure for objective weighting, Expert Systems with Applications 38(10): 12160-12167. http://dx.doi.org/10.1016/j.eswa.2011.03.027

Shepherd, D. A. 1999. Venture capitalists' assessment of new venture survival, Management Science 45(5): 621-632. http://dx.doi.org/10.1287/mnsc.45.5.621

Silva, J. 2004. Venture capitalists' decision-making in small equity markets: a case study using participant observation, Venture capital 6(2/3): 125-145. http://dx.doi.org/10.1080/13691060410001675974

Stedler, H.; Peters, H. 2003. Business angels in Germany: an empirical study, Venture Capital 5(3): 269-276. http://dx.doi.org/10.1080/1369106032000126596

Sudek, R. 2007. Angel investment criteria, Journal of Small Business Strategy 17(2): 89-103.

Tyebjee, T. T.; Bruno, A. V. 1984. A model of venture capitalists investment activity, Management Science 30(9): 1051-1066. http://dx.doi.org/10.1287/mnsc.30.9.1051

Van Osnabrugge, M. 2000. A comparison of business angel and venture capitalist investment procedures: an agency theory-based analysis, Venture Capital 2(2): 91-109.

http://dx.doi.org/10.1080/136910600295729 
Wang, Y. L.; Tzeng, G. H. 2012. Brand marketing for creating brand value based on a MCDM model combining DEMATEL with ANP and VIKOR methods, Expert Systems with Applications 39(5): 5600-5615. http://dx.doi.org/10.1016/j.eswa.2011.11.057

Wei, J.; Lin, X. 2008. The multiple attribute decision-making VIKOR method and its application, in 4th International Conference on Wireless Communications, Networking and Mobile Computing, 2008. WiCOM '08, IEEE, 12-14 October 2008, Dalian, 1-4.

Wei, G.; Zhao, X.; Wang, H. 2012. An approach to multiple attribute group decision making with interval intuitionistic trapezoidal fuzzy information, Technological and Economic Development of Economy 18(2): 317-330. http://dx.doi.org/10.3846/20294913.2012.676995

Wells, W. A. 1974. Venture capital decision making: Unpublished doctoral dissertation. Carnegie Mellon University, Pittsburgh.

Wu, H. Y.; Chen, J. K.; Chen, I. S. 2010. Innovation capital indicator assessment of Taiwanese Universities: a hybrid fuzzy model application, Expert Systems with Applications 37(2): 1635-1642.

http://dx.doi.org/10.1016/j.eswa.2009.06.045

Yang, Y. P. O.; Shieh, H. M.; Tzeng, G. H. 2013. A VIKOR technique based on DEMATEL and ANP for information security risk control assessment, Information Sciences 232(20): 482-500. http://dx.doi.org/10.1016/j.ins.2011.09.012

Yazdani-Chamzini, A.; Fouladgar, M. M.; Zavadskas E. K.; Moini, S. H. H. 2013. Selecting the optimal renewable energy using multi criteria decision making, Journal of Business Economics and Management 14(5): 957-978. http://dx.doi.org/10.3846/16111699.2013.766257

Yücenur, G. N.; Demirel, N. C. 2012. Group decision making process for insurance company selection problem with extended VIKOR method under fuzzy environment, Expert Systems with Applications 39(3): 3702-3707. http://dx.doi.org/10.1016/j.eswa.2011.09.065

Zacharakis, A.; Meyer, G. D. 1998. A lack of insight: do venture capitalists really understand their own decision processes?, Journal of Business Venturing 13(1): 57-76.

http://dx.doi.org/10.1016/S0883-9026(97)00004-9

Zadeh, L. A. 1965. Fuzzy sets, Information and Control 8(3): 338-353. http://dx.doi.org/10.1016/S0019-9958(65)90241-X

Zadeh, L. A. 1976. A fuzzy algorithmic approach to the definition of complex or imprecise concepts, International Journal of Man-Machine Studies 8(3): 249-291. http://dx.doi.org/10.1016/S0020-7373(76)80001-6

Zandi, A.; Roghanian, E. 2013. Extension of fuzzy ELECTRE based on VIKOR method, Computers \& Industrial Engineering 66(2): 258-263. http://dx.doi.org/10.1016/j.cie.2013.06.011

Zavadskas, E. K.; Antuchevičienè, J. 2008. Modelling multidimensional redevelopment of derelict buildings, International Journal of Environment and Pollution 35(2/3/4): 331-344.

Zavadskas, E. K.; Turskis, Z.; Volvačiovas, R.; Kildienė, S. 2013. Multi-criteria assessment model of technologies, Studies in Informatics and Control 22(4): 249-258. Bucharest: National Institute for Research \& Development in Informatics.

Zhang, N.; Wei, G. 2013. Extension of VIKOR method for decision making problem based on hesitant fuzzy set, Applied Mathematical Modelling 37(7): 4938-4947. http://dx.doi.org/10.1016/j.apm.2012.10.002

Zimmermann, H. J. 2001. Fuzzy set theory and its applications. 4th ed. Boston: Kluwer Academic Publishers. http://dx.doi.org/10.1007/978-94-010-0646-0

Zolfani, S. H.; Esfahani, M. H.; Bitarafan, M.; Zavadskas E. K.; Arefi, S. L. 2013. Developing a new hybrid MCDM method for selection of the optimal alternative of mechanical longitudinal ventilation of tunnel pollutants during automobile accidents, Transport 28(1): 89-96.

http://dx.doi.org/10.3846/16484142.2013.782567 
Reza ROSTAMZADEH. Doctor, currently a Postdoctoral Researcher at Universiti Teknologi Malaysia (UTM). He is the author and co-author of more than 10 research papers and reviewer of the several distinguished journals. His research interests include supply chain management, multi criteria decision making, operations management and entrepreneurship.

Kamariah ISMAIL. Doctor, Associate Professor at the Business Administration Department of Universiti Teknologi Malaysia (UTM) and Director of UTM Technology Entrepreneurship Centre (UTMTEC). She is the author and co-author of more than 80 articles, 35 conference papers and also has been worked in many consultancy projects. Research interests are innovation, commercialisation, and entrepreneurship.

Edmundas Kazimieras ZAVADSKAS. PhD, DSc, h.c.multi. Prof., Head of the Department of Construction Technology and Management at Vilnius Gediminas Technical University, Lithuania. Senior Research Fellow at the Researcher of Research Institute of Smart Building Technologies. A member of Lithuanian and several foreign Academies of Sciences. Doctore Honoris Causa from Poznan, Saint-Petersburg and Kiev universities. The Honorary International Chair Professor in the National Taipei University of Technology. A member of international organizations; a member of steering and programme committees at many international conferences; a member of editorial boards of several research journals; the author and co-author of more than 400 papers and a number of monographs in Lithuanian, English, German and Russian. Editor-in-Chief of journals Technological and Economic Development of Economy and Journal of Civil Engineering and Management. Research interests: building technology and management, decision-making theory, automation in design and decision support systems. 